Volume 8, No.1.3, 2019

International Journal of Advanced Trends in Computer Science and Engineering

Available Online at http://www.warse.org/IJATCSE/static/pdf/file/ijatcse3081.32019.pdf

https://doi.org/10.30534/ijatcse/2019/3081.32019

\title{
Do the Multiplication (Dothem): A Mobile App to Improve Multiplication Techniques for Level 2 Primary School Students
}

\author{
Subashini Annamalai ${ }^{1}$, Jasni Ahmad ${ }^{2}$ \\ ${ }^{1}$ Universiti Utara Malaysia, subashini@uum.edu.my \\ ${ }^{2}$ Universiti Utara Malaysia, jasni@uum.edu.my
}

\begin{abstract}
Learning multiplication is often considered as difficult by the primary school students. However, it can be made easy by using a motivating and engaging technology-based instructional material such as a mobile application. Taking that into consideration, this study attempts to investigate the effects of a mathematical mobile application named as Do The Multiplication (DoTheM) on improving the understanding of multiplication techniques among the Level 2 primary school students. DoTheM is designed and developed based on the Year 4 and Year 5 syllabus and contains five multiplication techniques, namely Japanese, Vedic Math, Anyone, Multi II and Fast Maths. This study employed a single group experimental design with a sample of 30 Level 2 primary school students. The data analysis for this study involves descriptive analysis and paired sample analysis. The findings of this study showed that there are significant differences in their achievement and understanding of the multiplication operations when the students experience the DoTheM app. The results suggest that the DoTheM mobile application could improve the Level 2 primary students' ability to solve multiplication operations using the five techniques illustrated in the mobile application.
\end{abstract}

Key words : DoTheM, multiplication technique, mobile application, primary, level 2.

\section{INTRODUCTION}

Multiplication facts are one of the basic skills in mathematics. The Mathematics syllabus of Integrated Primary School Curriculum (KBSR) has placed a high emphasis on fostering the understanding of concepts and skills multiplication facts [1]. Although the focus of learning multiplication facts is one of the important aspects of the curriculum, but there are still many students who have difficulties mastering the operation well [2]-[7].

Learning multiplication facts is a key issue in mathematics in primary schools ${ }^{8}$. Past research has shown that a lack skill of the multiplication facts is one of the causes of low achievement in mathematics [2], [5], [9]-[11]. This is because multiplication facts highly contribute to problem solving techniques that is crucial in solving mathematical problems. It is difficult for the students to solve any mathematical problems if they do not master the multiplication facts [12]. This will cause them to lose interest in mathematics which will eventually affect their mathematics performance.

One reason that is said to be a factor that causes the students to have difficulties mastering the multiplication facts is the inappropriate teaching method [13]-[14]. There is a call for the teachers to adopt the technological based instructional materials to achieve the intended learning outcomes.

Based on this call and extended literature reviews, this study attempts to investigate the effectiveness of a mobile application, namely Do The Multiplication (DoTheM) that illustrates multiplication techniques, in improving multiplication skills of the level 2 primary school students.

\section{ISSUES IN LEARNING MULTIPLICATION}

Mathematics achievement is directly related to the abilities of the students to master numbers of operations. One of the operations that the students need to master is the multiplication facts. When the students are not able to master the multiplication facts, they will face difficulties answer multiplication and division questions. This will affect the interest of the students to learn mathematics. Eventually this will lead to low achievement in mathematics. Thus, the educators should focus on the multiplication facts teaching and learning methods to improving students' multiplication skills.

Currently, the teaching and learning of multiplication facts at the primary school level, uses the traditional 'chalk and talk' methods15. Researchers claim that memorization exercises are the common activity used to teach and learn multiplication facts16-18. However, it only aims to force the students to remember the facts without understanding the multiplication concepts. When the students need to use the facts to solve problems, they are unable to do it. This causes the students to feel quickly tired and less motivated to learn multiplication facts because using too much time to memorize the multiplication facts without understanding it [5], [6], [10], [16], [19].

Therefore, the teachers need to use appropriate teaching methods to help the students to understand the multiplication techniques [17], [20]-[23]. The student should also practice using the multiplication facts. This will encourage the active involvement of students in the learning multiplication facts. 
When students do exercises related to the learning content, the information storage rate will be higher compared to other methods that have less participation of students such as lectures, reading (memorization), audiovisual, demonstrations and group discussions [23]-[24].

\section{DO THE MULTIPLICATION (DoTheM) MOBILE APPLICATION}

DoTHEM aims to enhance multiplication skills of Year 4, 5 and 6 primary students. DoTHEM is developed for the reason that the traditional learning technique is slower and often inaccurate compared to the animated learning techniques in DoTHEM. Not only that it has step-to-step animation tutorials of the multiplication techniques, it also provides a redundant audio explanation of the techniques. It illustrates five multiplication techniques, namely Japanese, Vedic Math, Anyone, Multi II and Fast Maths. The content covers the animated tutorial, activities and test. The test assessments also give feedback to the students whether the answer is correct or incorrect. There is also a summary of all the multiplication techniques. The summary will show the students on which technique should they use for a certain type of question. Figure 1 illustrates the interfaces of the DoTheM mobile application.

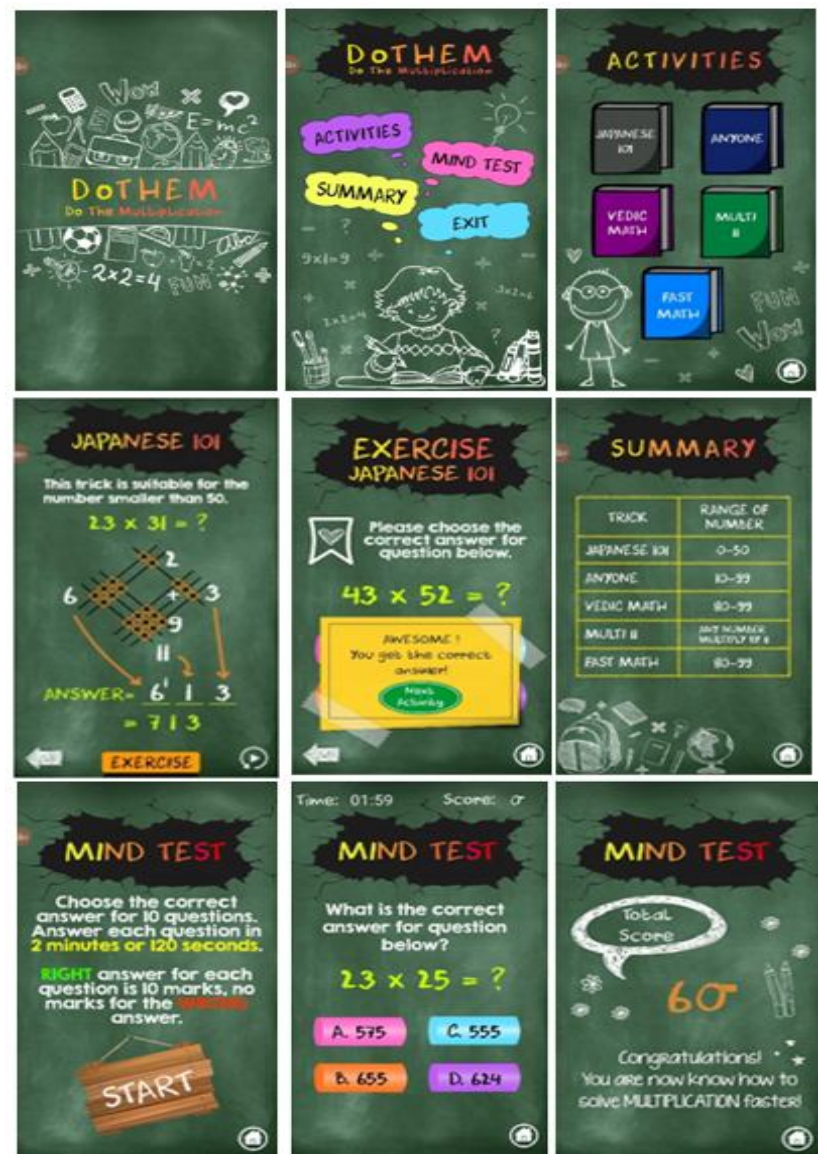

Figure 1: DoTheM interfaces.

DoTheM provides a multi-genre tutorial space that engages and draws the primary students into a different interaction with multiplication facts. It also appeals to multiple learning modalities as it provides embedded mixture of visual (text) and audio (sound, music or voice) that enables the students to learn through their preferred modality.

Students are able to learn multiplication facts and techniques while creating and integrating 'schema' to understand better and freely at their own will. They may repeat the content as many times as they want for them to understand each step of the techniques better. The combinations of multimedia elements in DoTheM offer the students a welcome change from chalk-and-talk classroom and also arouse their interest in learning. The redundancy of multimedia (text, narration, animation and graphics) in DoTheM also works together in improving the learning process.

A comparative analysis was conducted to compare DoTheM with 10 existing Mathematical apps that cover the multiplication techniques. However, not all of the mobile apps has exercises and feedbacks that could help the students learn multiplication techniques properly.

DoTheM is designed to have all the important features such as animated tutorial, narration, background music, assessment (exercise), feedback and score. Table 1 shows the comparison of different functions or features of the existing mobile apps with DoTheM.

Table 1: Comparison of different Mathematics mobile application with DoTheM.

\begin{tabular}{|c|c|c|c|c|c|c|c|c|}
\hline Application Name & Exercise & Score & Timing & Theme & Audio & $\begin{array}{l}\text { Background } \\
\text { music }\end{array}$ & Notepad & $\begin{array}{c}\text { Animated } \\
\text { teaching }\end{array}$ \\
\hline math tricks & & & & & & & I & \\
\hline Math Tricks & I & I & I & I & & & & \\
\hline 1100 Math Tricks & & & & I & & & & \\
\hline Rapid Math Tricks \& Tips & & & & I & I & & & \\
\hline Math games & I & I & I & & & & & \\
\hline Math Tricks Workout & I & I & I & & & & & \\
\hline Math Tricks & I & I & I & I & & & & \\
\hline Math Tricks & & & & I & & & & \\
\hline CoolVedic Maths Tricks & I & I & & & & & & \\
\hline Tricky Maths & I & I & I & & & & & \\
\hline DoTheM & I & I & I & & I & I & & I \\
\hline
\end{tabular}

\section{METHODOLOGY}

\subsection{Sample}

A sample of 30 Year 4, 5 and 6 primary school students was randomly chosen from three national schools in Malaysia. They are homogenous in terms of their average multiplication skills, whereby they are required to sit for a simple ten-minute multiplication test to assess their knowledge, prior to the intervention.

\subsection{Instruments}

The students were assigned to DoTheM, the mobile application for multiplication that is aimed to help the students to learn different multiplication techniques. DoTheM 
encompasses the animation of five different techniques with examples and assessments.

The instruments used for this study were a pre-test and a post-test to measure the students' multiplication skill. The test consists of 10 questions that required them to use a different technique to solve it.

\subsection{Research Procedure}

Prior to the intervention, the students were given the pre-test questions for twenty minutes. Then, they were assigned the DoTheM individually, and they have used the mobile application for two hours to experience the learning content. Finally, they were given twenty minutes to answer the post-test questions. Figure 2 illustrated the research procedures.

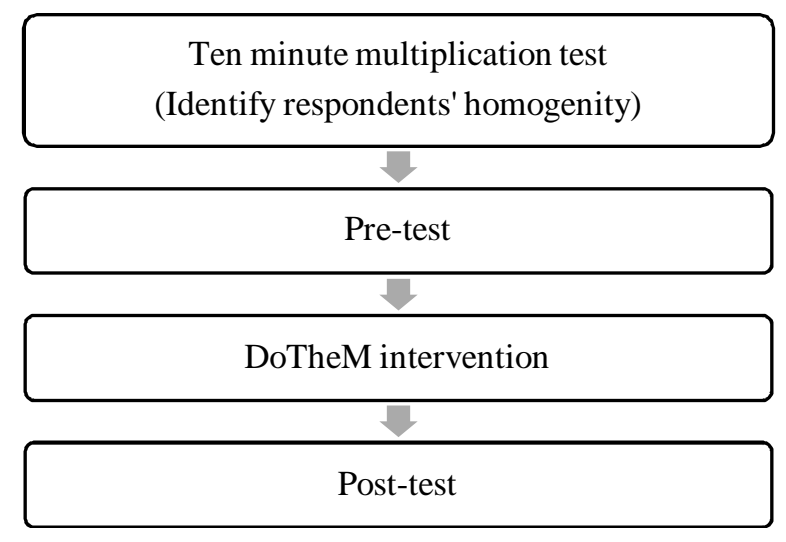

Figure 2: Research Procedures

\section{FINDINGS}

The analyses of the data were carried out through parametric statistical techniques. The primary students experienced the DoTheM mobile application and answered ten multiplication questions. The students were given the pre-test prior to the intervention and the post-test after the intervention. The multiplication questions tested the students on the understanding of different problem-solving techniques. The scores are obtained to measure the students' multiplication facts understanding. From the analysis, the mean of the all the post-test scores $(\bar{X}$ post $1=8.37 ; \bar{X}$ post $2=8.42 ; \bar{X}$ post $3=$ $8.32 ; \bar{X}$ post $4=8.22 ; \bar{X}$ post $5=8.05 ; \bar{X}$ post $6=8.08 ; \bar{X}$ post 7 $=8.73 ; \bar{X}$ post $8=8.43 ; \bar{X}$ post $9=8.52 ; \bar{X}$ post $11=8.32)$ are relatively higher than pretest scores $(\bar{X}$ pre1 $=4.00 ; \bar{X}$ pre2 $=$ $3.74 ; \bar{X}$ pre3 $=2.87 ; \bar{X}$ pre4 $=3.37 ; \bar{X}$ pre5 $=2.68 ; \bar{X}$ pre6 $=$ $2.93 ; \bar{X}$ pre7 $=2.87 ; \bar{X}$ pre $8=3.35 ; \bar{X}$ pre9 $=4.18 ; \bar{X}$ pre10 $=$ 3.37). These higher post-test mean scores indicated that the sample students were able to answer the multiplication questions better after the DoTheM intervention as it illustrates various animated step-by-step multiplication techniques for them to understand. The students were also able to finish the post-test questions faster than the pretest as they know the appropriate techniques to use for each question given. The descriptive statistical analysis of the programming comprehension scores is depicted in Table 2.
Figure 3 illustrates the linear graph for the descriptive statistics for pre-test and post-test mean scores of the multiplication tests. The graph depicts that there is an increase in the mean scores of post-test, indicating that the students are able to understand the multiplication facts better when they used DoTheM.

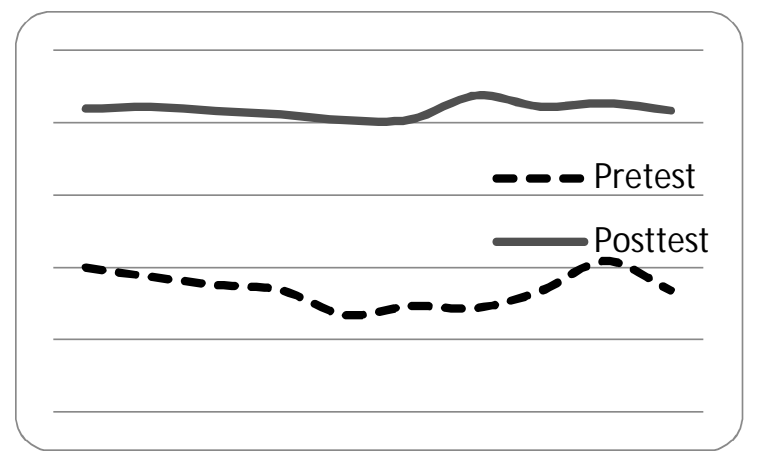

Figure 3: Descriptive illustration for pre-test and post-test mean scores

Table 2: Descriptive analysis of the pre-test and post-test mean scores

\begin{tabular}{|c|c|c|c|c|}
\hline Mode & Question & $\begin{array}{l}\text { Number } \\
\text { of } \\
\text { students }\end{array}$ & $\begin{array}{c}\text { Mean } \\
\text { (Score) }\end{array}$ & Std. Dev \\
\hline \multirow{10}{*}{ Pretest } & 1 & \multirow{10}{*}{30} & 4.00 & 2.017 \\
\hline & 2 & & 3.74 & 2.104 \\
\hline & 3 & & 3.52 & 1.891 \\
\hline & 4 & & 3.37 & 1.751 \\
\hline & 5 & & 2.68 & 1.550 \\
\hline & 6 & & 2.93 & 1.924 \\
\hline & 7 & & 2.87 & 1.513 \\
\hline & 8 & & 3.35 & 1.682 \\
\hline & 9 & & 4.18 & 1.689 \\
\hline & 10 & & 3.37 & 1.865 \\
\hline \multirow{10}{*}{ Post-test } & 1 & \multirow{10}{*}{30} & 8.37 & .927 \\
\hline & 2 & & 8.42 & .974 \\
\hline & 3 & & 8.32 & 1.102 \\
\hline & 4 & & 8.22 & 1.022 \\
\hline & 5 & & 8.05 & 1.147 \\
\hline & 6 & & 8.08 & 1.070 \\
\hline & 7 & & 8.73 & 1.023 \\
\hline & 8 & & 8.43 & 1.056 \\
\hline & 9 & & 8.52 & .995 \\
\hline & 10 & & 8.32 & 1.086 \\
\hline
\end{tabular}




\section{DISCUSSION}

Primary students are having difficulties encountering the multiplication operations and often have problems to understand the abstract concepts and applying them to the problem solving questions. The ultimate goal of this research is to bring a multimedia approach into the curriculum of Mathematics to help the primary students who had difficulties with learning multiplication.

The data gathered from this study measured the students' multiplication facts understanding. For this, the students were given the pre-test prior to the intervention and the post-test after the intervention. The multiplication questions tested the students on the understanding of different problem-solving techniques. The analysis of the mean scores indicated that the students were able to answer the multiplication questions better after the DoTheM intervention. The statistical analysis also indicated that using multimedia approach in the mode of mobile application such as DoTheM to facilitate and learn multiplication facts can bring benefits. It helped the primary students to understand various multiplication techniques and apply the abstract concepts in a problem-solving context. When the students are able to understand the multiplication concepts, they will comprehend the operation better and will be motivated to learn the multiplication facts as it ensures same chances for the students with different dominant senses with getting more information, deeper comprehension, and better perception using the multimedia approach. This will help the students to change their perceptions towards multiplication operation problems.

Mobile application such as DoTheM that has redundant multimedia elements will also help the mathematic teachers teach the abstract multiplication techniques which are difficult to explain. The step-by-step animated teaching can help the students to understand the techniques at the own pace. As for the parents, they also can learn the multiplication techniques faster by using this mobile application and assist their children in learning multiplication facts using various techniques.

\section{CONCLUSION}

This study examines the effectiveness of Do The Multiplication (DoTheM) mobile application using pre and post test single group experimental design. DoTheM is designed for Level 2 primary students, namely the Year 4, 5 and 6. It covers five multiplication techniques; Japanese, Vedic Math, Anyone, Multi II and Fast Maths and is developed based on the Malaysia's Integrated Primary School Curriculum (KSSR). The content of DoTheM includes the animated tutorial, activity and an enhancement test. A total of 30 students was selected as respondents. And this study found that DoTheM is effective in improving the Level 2 primary students' multiplication skills and techniques. Thus, DoTheM can be used as an instructional aid in schools to help the students' in enhancing the mathematical operation.

The findings of this study may have good implications for students, parents, teachers, the Ministry of Education and other researchers pertaining the teaching and learning the multiplication facts.

\section{ACKNOWLEDGEMENT}

The authors would like to thank their students, Kia Xin Yee and Lim Yi Xin for their effort to design and develop the DoTheM mobile application.

\section{REFERENCES}

1. Pusat Perkembangan Kurikulum Kementerian Pelajaran Malaysia.Kementerian Pelajaran Malaysia. (Kurikulum Standard Sekolah Rendah Matematik Tahun Empat: Dokumen Standard Kurikulum Dan Pentaksiran (Draf Edition) (2013). Kementerian Pelajaran Malaysia.

2. Aida I (2006). Meningkatkan kemahiran murid mencongak fakta asas darab melalui pendekatan permainan, Jurnal Kajian Tindakan Negeri Johor, 1-13.

3. Anghileri $\mathbf{J}$ (2008). Uses of counting in multiplication and division. In I. Thompson (Ed.), Teaching And Learning Early Number (2nd ed.), England: Open University Press, 110-121.

4. Iskandar SI, \& Asbullah B (2010). Penggunaan jari jemari untuk memudahkan murid-murid tahun 4 menghafal sifir 9. Proceeding of the Seminar Penyelidikan Tindakan (Matematik Pendidikan Rendah), 134-142.

5. Tambychik T \& Thamby SM (2010). Students' Difficulties in Mathematics Problem-Solving: What do they Say?, Procedia - Social and Behavioral Sciences, 8, 142-151. https://doi.org/10.1016/j.sbspro.2010.12.020

6. Mahler JD (2011). When Multiplication Facts Won't Stick: Could a Language/Story Approach Work? A research study examining the effectiveness of the "Memorize in Minutes" curriculum, The Educational Therapist, 32, 5-21.

7. Forgues HL, Tian J \& Siegler RS (2015). Why is learning fraction and decimal arithmetic so difficult?, Developmental Review, 38, 201-221.

https://doi.org/10.1016/j.dr.2015.07.008

8. Gardella FJ (2009). Introducing difficult mathematics topic in the elementary classroom: A teacher's guide to initial lessons. New York: Routledge Taylor \& Francis Group. https://doi.org/10.4324/9780203891179

9. Pia KF (2015). Barriers in Teaching Learning Process of Mathematics at Secondary Level: A Quest for Quality Improvement, American Journal of Educational Research, 3, 822-831.

10. Thai LK, \& Mohd. Hanafi MY (2016). Magic Finger Teaching Method in Learning Multiplication Facts among Deaf Students, Journal of Education and Learning, 5, 40-50. https://doi.org/10.5539/jel.v5n3p40

11. DeMaioribus CE (2011). Automaticity of Basic Math Facts: The Key To Math Success? Unpublished Master's Thesis, University of Minnesota Duluth. 
12. Braddock S (2010). Developing Fourth Graders' Proficiency In Basic Multiplication Facts Through Strategy Instruction, Unpublished Master's Thesis, University Of Central Florida.

13. Gabriel F, Coché F, Szucs D, Carette V, Rey B, \& Content A (2013). A componential view of children's difficulties in learning fractions, Front Psychol, 4, $15-730$. https://doi.org/10.3389/fpsyg.2013.00715

14. Kamariah AB, Rohani AT, Sharifah MN, Wan Zah WA, \& Ramlah H (2010). Teachers and Learners' Perspectives on Learning Mathematics for At-Risks Students, Procedia Social and Behavioral Sciences, 8, 393-402. https://doi.org/10.1016/j.sbspro.2010.12.055

15. Norasmah O, Shuki O (2010). Kaedah pengajaran dan pembelajaran. In I. Noraini, \& O. Shuki (Eds.), Pengajaran dan pembelajaran: teori dan praktis, Bangi: Universiti Kebangsaan Malaysia., 75-100.

16. Boaler J (2015). Fluency Without Fear: Research Evidence on the Best Ways to Learn Math Facts, Youcubed.

17. Sullivan P (2011). Teaching Mathematics: Using research-informed Strategies. Australian Council for Educational Research, 1-80.

18. Dunlosky J, Rawson KA, Marsh EJ, Nathan MJ, \& Willingham DT (2013). Improving Students' Learning With Effective Learning Techniques: Promising Directions From Cognitive and Educational Psychology, Psychological Science in the Public Interest, 14, 4-58. https://doi.org/10.1177/1529100612453266

19. Herold SA (2013). Effectiveness of Paper-Based, Computer-Based, and Interactive Learning Strategies for Recall of Multiplication Facts, Unpublished Master's Thesis, Ohio University.

20. Tucker BF, Singleton AH, \& Weaver TL (2006). Teaching mathematics to all children: Designing and adapting instruction to meet the needs of diverse learners (2nd ed.). New Jersey: Pearson Merill Prentice Hall.

21. Mat Zin NA (2009). A-MathS Multimedia Courseware for Effective Mathematic Learning: Matching Instructions to Student's Learning Style. Journal of Applied Sciences, 9, 1510-1516. https://doi.org/10.3923/jas.2009.1510.1516

22. Ussher J, Damoah D, Ansong ED, Quarshie H, Adjetey C \&. Poakwah G (2014). The Effectiveness Of Interactive Multimedia Courseware As Instructional Medium For Teaching, British Journal of Education, 2, 36-47.

23. Bryant BR, Ok M, Kang EY, Kim MK, Lang R, Bryant DP \& Pfannestiel K (2015). Performance of Fourth-Grade Students with Learning Disabilities on Multiplication Facts Comparing Teacher-Mediated and Technology-Mediated Interventions: A Preliminary Investigation, Journal of Behavioral Education, 24, 255-272. https://doi.org/10.1007/s10864-015-9218-z

24. Sousa DA (2006). How the brain learns (3rd ed.). California: A Sage Publications Company. 